\title{
NODDING ONION (ALLIUM CERNUUM), A RARE PLANT IN SASKATCHEWAN
}

HYEOK JAE CHOI, Korea National Arboretum, Division of Forest Biodiversity and Herbarium, 51-7 Jikdong-Ri, Seoul, Republic of Korea, and Department of Biology, University of Saskatchewan, Saskatoon, SK, S7N 5E2; and J. HUGO COTASÁNCHEZ, Department of Biology, University of Saskatchewan, Saskatoon, SK, S7N 5E2, and W. P. Fraser Herbarium (SASK), University of Saskatchewan, Saskatoon, SK, S7N 5A8; E-mail: <hugo.cota@usask.ca>

The genus Allium L., has been traditionally circumscribed in the tribe Allieae of the Liliaceae, ${ }^{5,10}$ but recently, several authors have placed this genus in its own family Alliaceae. ${ }^{1,2,9}$ The genus Allium is characterized by the presence of bulbs enclosed in membranous (sometimes finely fibrous) tunicas, free or almost free tepals, and often a subgynobasic style (style arising near the base of the gynoecium). The mesophyll cells of most taxa produce remarkable amounts of cysteine sulfoxides, the complex chemicals that are responsible for producing the characteristic and familiar odor and taste of onions, garlic, and chives, and which may have potential therapeutic effects. ${ }^{3}$

The genus Allium includes ca. 700 species widely distributed in the northern hemisphere, especially in the temperate regions of Eurasia, but it is also found in the southern hemisphere in regions of Africa and Central and South America. ${ }^{79,10}$ It has a main center of diversity in southwestern and central Asia and a smaller secondary area of diversification in North America. Thirteen taxa, excluding cultivated or introduced species, are known to exist in Canada. According to Harms' 2003 checklist of Saskatchewan plants, five Allium species ( $A$. cernuum Roth, $A$. geyeri S. Wats., A schoenoprashum L., A. stellatum Ker Gawler, and A. textile A. Nels. \& Macbr.) are distributed in Saskatchewan. ${ }^{4}$ However, based on our observations of specimens in the W. P. Fraser Herbarium (SASK), we have come to the conclusion that $A$. geyeri does not occur in Saskatchewan.

The purpose of this paper is to provide an update on the occurrence of Allium cernuum (Nodding Onion), a rare provincial species, and document the status of Saskatchewan populations with an emphasis on the southern population without disclosing exact localities. We expect the information on this species will be useful for future monitoring and conservation programs, assessments of rarity status, population dynamics and genetic diversity. Allium cernuum (Fig. 1) (see inside front cover) is one of the most widespread North American species of the genus. Despite its wide distribution, this species is quite rare in Saskatchewan and is ranked as 'S1S2' by the Saskatchewan Conservation Data Centre (SCDC). ${ }^{8}$ According to the SCDC, the $S 1$ ranking denotes extremely rare species (five or fewer occurrences) while S2 indicates rare species (six to 20 occurrences). In turn, Harms included this species in the vulnerable (VUL) category, 


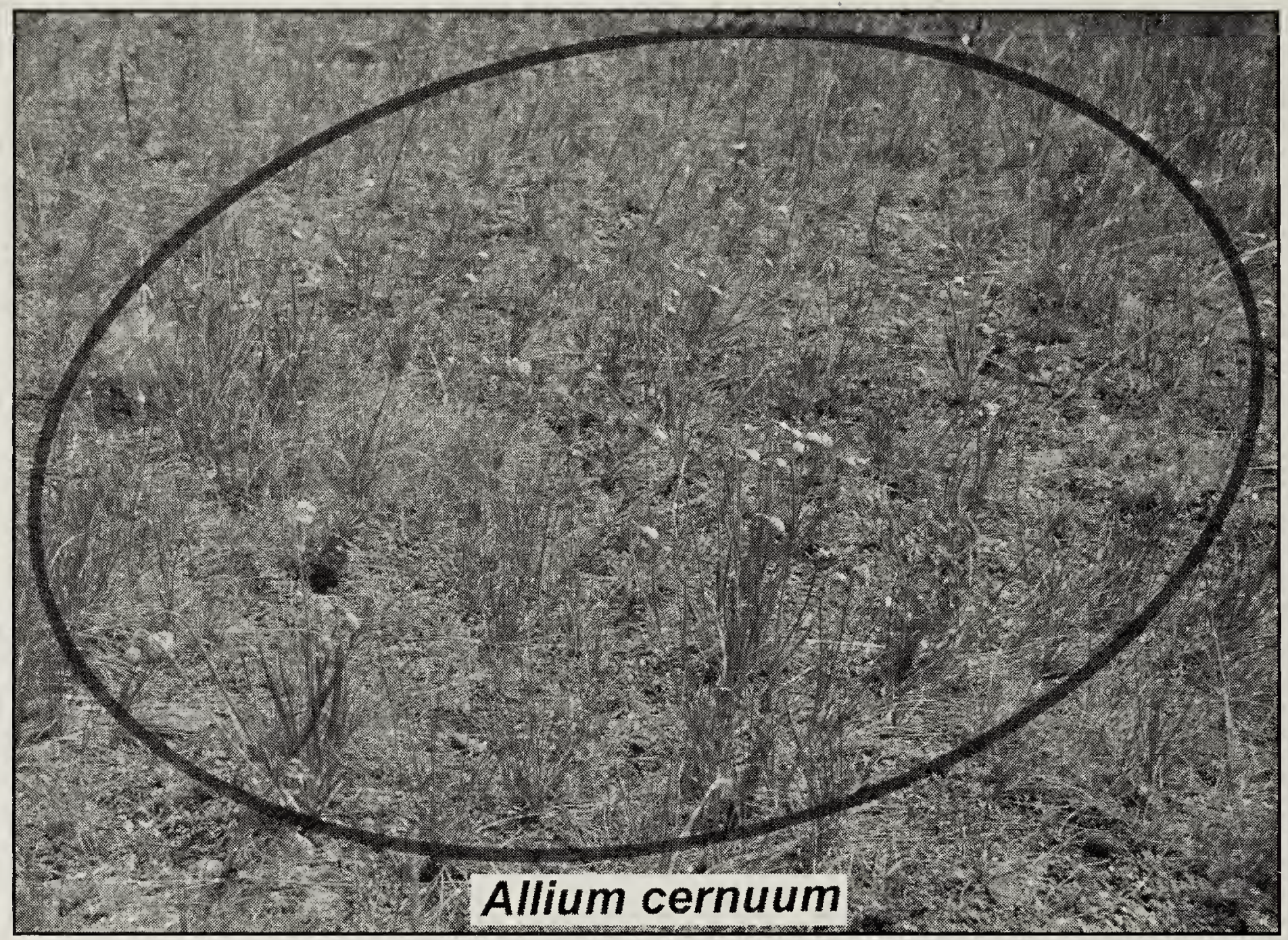

Figure 2. Habitat and population of Allium cernuum (circled) in southwestern Saskatchewan. Note the flower buds in the specimens. Photo taken in July 2009.

indicating species at risk, because of its declining numbers with subsequent special concern. ${ }^{4}$

Taxonomically, Allium cernuum is closely related to $A$. stellatum. The character most commonly used to differentiate these two species is the orientation of the umbelshaped inflorescence. In both species, the inflorescence may often be nodding in the budding stage, but in $A$. stellatum, the inflorescence usually becomes erect during anthesis. In A. cernuum, the peduncle remains permanently curved near the apex (Fig. 1A) (see inside front cover, top); however, the inflorescence may sometimes become erect or nearly so. ${ }^{6}$ In addition, the perianth shape in $A$. cernuum is campanulate with ascending tepals, whereas in A. stellatum, it is stellate with apically spreading tepals.

To our knowledge, various populations of Allium cernuum have been reported in two main localities, one in the Meadow Lake area (central western Saskatchewan) and another in the Cypress Hills region (southwestern Saskatchewan). It has also been collected near Yorkton in southeastern Saskatchewan. In July 2009, we conducted fieldwork and found Nodding Onion in the southwestern region of Saskatchewan. The populations were located near roads and margins of cliffs at an altitude of ca. $1300 \mathrm{~m}$ growing together with Apocynum androsaemifolium L., Campanula rotundifolia L., Eriogonum flavum Nutt., Monarda fistulosa L., and Potentilla fruticosa L. (= Dasiphora fruticosa L.), among others. Contrary to the Flora of North America, which indicates that $A$. cernuum prefers moist soils in mountainous and cool regions, ${ }^{6}$ the SW Saskatchewan population of Nodding Onion is distributed on dry gravelly to sandy soils. The individuals of this population were not fully blooming. Most plants had flower buds near to 
anthesis (Fig. 2). Fortunately, we were able to find some plants with flowers, from which we observed floral organs, such as the entire filament margins and the characteristic crested ovary (Fig. 1C) (see inside front cover, top). In addition, reproductive parts preserved in $70 \%$ ethanol $(\mathrm{EtOH})$ from one herbarium voucher and from 20 other samples collected from living specimens in ten colonies (two individuals per colony) of the same locality, are being investigated.

Based on field observations, the flowering time of this Saskatchewan population is from the second week of July to the first week of August (although 2009 may have been a somewhat atypical year for phenotypic observations; $V$. Harms, University of Saskatchewan, pers. comm.). In terms of population size and number of individuals, our numerical estimate of this rare species in southwestern Saskatchewan is about 300 individuals, distributed in ca. 0.5 ha. The largest population we measured occupied an area of ca. $2 \mathrm{~m}^{2}$, in which we estimated 70 blooming individuals (Fig. 2). In some areas, this plant was locally abundant to the extent that it formed an herb mat.

According to herbarium records from 1949 and 1950 at SASK, Allium cernuum has been collected at Meadow Lake, Alcott Creek, and two other nearby areas in the west central portion of the province. Nonetheless, the original habitat, fescue prairie, indicated in voucher specimens no longer exists, especially in areas near roads. In addition, the relatively recent clearing of the original vegetation and the prevailing habitats in Alcott Creek and surrounding areas, which are quite swampy and unsuitable for $A$. cernuum to grow, have apparently played a major role in the waning of this population $(\mathrm{K}$. Remarchuk, University of Saskatchewan, pers. comm.). In turn, the Central Block locality of the Cypress Hills population was visited this summer, but only two individuals were found. Although the West Block population was not visited, the apparently low rate of reproduction of this species in the Central Block is reflected in the low number of individuals. However, more intensive field work is necessary to make a more accurate assessment of the current populations.

Some inferences can be made with these data and observations. Foremost, it appears that the general Meadow Lake area population may have vanished, at least from the most accessible areas, due primarily to human activities, which suggests the enforcement of better conservation practices in the preservation of species at risk. Secondly, while our data for the southwestern population are encouraging in terms of population number, this species might not be within the S1S2 rank as indicated by the SCDC, and Harms' vulnerable status may be more appropriate, as this species is locally abundant. However, considering that the existence of the Meadow Lake population is questionable, we recommend continuing to rank this species as S1S2 until more extensive surveys of this and the Cypress Hills populations are conducted.

\section{Acknowledgements}

We thank G. Lee for information about the southwestern population, $K$. Remarchuk for information on the Meadow Lake population, and V. Harms for his comments on an early draft of the manuscript. We are also grateful to the personnel of the W. P. Fraser Herbarium (SASK) for their assistance with loan material. Research for this article was partly supported by a grant (Project No. C00659) from the Korea Research Foundation.

1. DAHLGREN, R. M. T., H. T. CLIFFORD, and F. T. YEO. 1985. The Families of the Monocotyledons. Springer-Verlag, Berlin, Heidelberg, New York, Tokyo. 
2. FRIESEN, N., R. M. FRITSCH, S. POLLNER, and F. R. BLATTNER. 2000. Molecular and morphological evidence for an origin of the aberrant genus Milula within Himalayan species of Allium (Alliaceae). Molecular Phylogenetics and Evolution 17:209218.

3. FRIESEN, N., R. M. FRITSCH, and F. R. BLATTNER. 2006. Phylogeny and new intrageneric classification of Allium (Alliaceae) based on nuclear ribosomal DNA ITS sequences. Aliso 22:372-395.

4. HARMS, V. L. 2003. Checklist of the Vascular Plants of Saskatchewan and the Provincially and Nationally Rare Native Plants of Saskatchewan. University Extension Press, University of Saskatchewan, Saskatoon, Saskatchewan.

5. LAWRENCE, G. H. M. 1951. Taxonomy of Vascular Plants. Macmillan Publishing Co., New York, New York.

6. MACNEAL, D. W., and T. D. JACOBSEN. 2002. Allium L. In: Flora of North America Ed. Committee (ed.), Flora of North America. NYBG Press, New York, New York.

7. RAHN, K. 1998. Alliaceae. In: K. Kubitzki (ed.), The Families and Genera of Vascular Plants, 3. Springer, Berlin and Heidelberg. p. 70--76.

8. SASKATCHEWAN CONSERVATION DATA CENTRE. 2009. Saskatchewan. Vascular Plant Species List. Regina, Saskatchewan. Available via the Internet at: <http://www.biodiversity.sk.ca/Docs/ ranking.pdf>.

9. TAKHTAJAN, A. 1997. Diversity and Classification of Flowering Plants. Columbia University Press, New York, New York.

10. XU, J.-M. 2000. Allium L. In: Raven, P. H. (ed.). Flora of China, 24: 95-133. Science Press and Missouri Botanical Garden Press, Beijing and St. Louis.

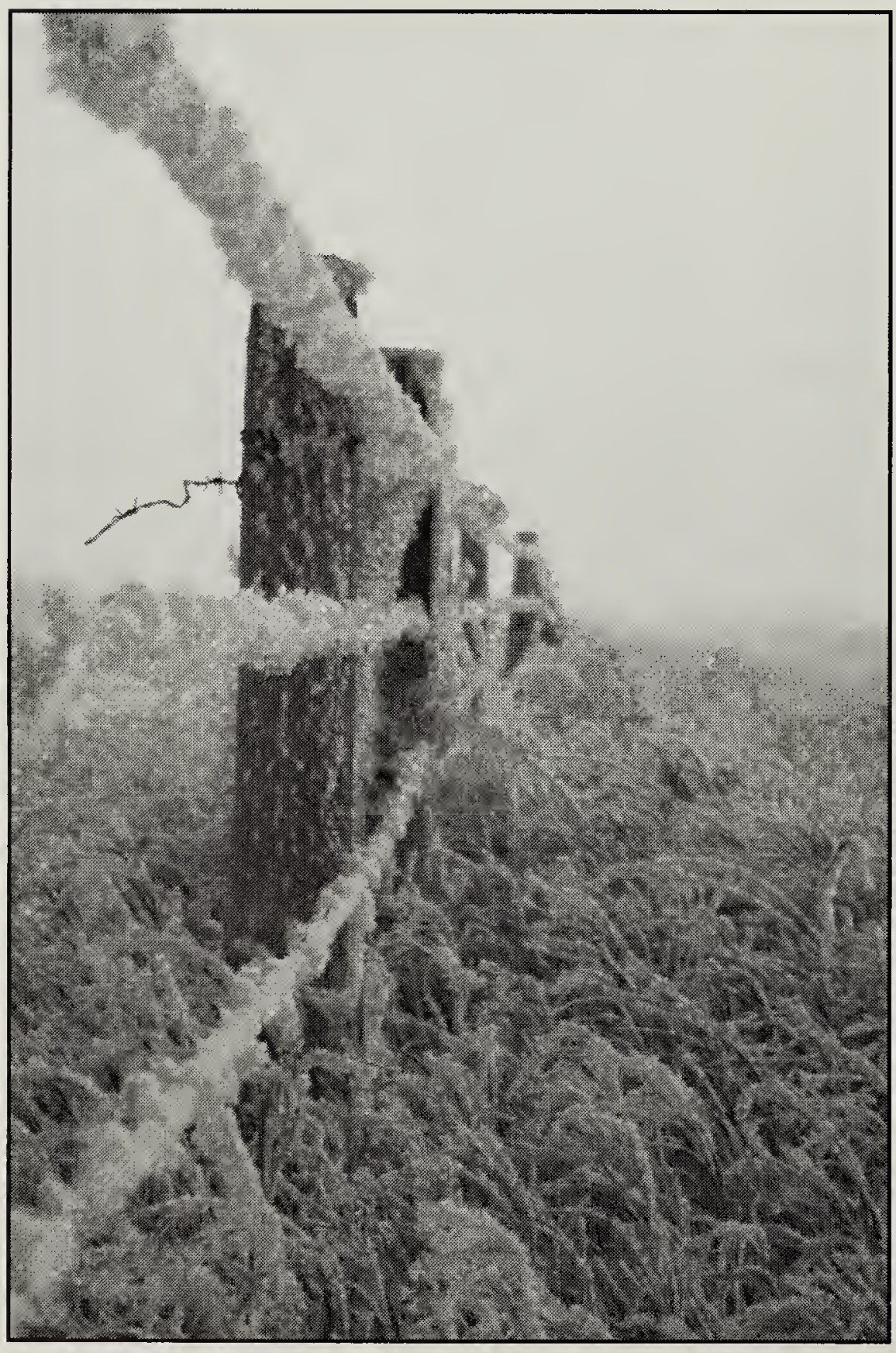

Frosty fence line.

Kerry Hecker 